\title{
IMPLEMENTASI KEBIJAKAN TRANSPORTASI ON LINE STUDI KASUS DI DKI JAKARTA
}

\author{
Dr. Bambang Istianto \\ Dosen STTD \\ J1. Raya Setu No. 89, Cibuntu, \\ Cibitung, Bekasi 17520 \\ Telp./Fax : (021) 8254640
}

\author{
Dr. Djajadi, MM \\ Dosen STTD \\ Jl. Raya Setu No. 89, Cibuntu, \\ Cibitung, Bekasi 17520 \\ Telp./Fax : (021) 8254640
}

\author{
Drs. Fauzi, MT \\ Dosen STTD \\ J1. Raya Setu No. 89, Cibuntu, \\ Cibitung, Bekasi 17520 \\ Telp./Fax : (021) 8254640
}

\author{
Drs. Margono \\ Dosen STTD \\ Jl. Raya Setu No. 89, Cibuntu, \\ Cibitung, Bekasi 17520
}

Telp./Fax : (021) 8254640

\author{
Arief Aprilianto, A.Ma.PKB \\ Instruktur STTD \\ Jl. Raya Setu No. 89, Cibuntu, \\ Cibitung, Bekasi 17520
}

Telp./Fax : (021) 8254640

\begin{abstract}
ABSTRAKSI
Penelitian ini bertujuan untuk mengetahui seberapa tinggi tanggapan atau respon para operator transportasi on line yaitu; pengemudi transportasi online, pemilik kendaraan, pengguna transportasi online dan pengemudi Taxi konvensional serta pengelola transportasi online, berkaitan dengan kebijakan pemerintah tentang transportasi online melalui Peraturan Menteri Perhubungan Nomor 32 Tahun 2016 Tentang Penyelenggaraan Angkutan Orang Dengan Kendaraan Bermotor Umum Tidak dalam Trayek.

Motode penelitian ini berdasarkan motode penelitian kualitatif dengan menggunakan strategi studi kasus serta metode analisis diskriptif terhadap setiap kelompok responden melalui instrument questioner tertutup dan dianalisis secara prosentase dari masing masing item pertanyaan yang disajikan secara grafis.

Hasil penelitian ini menemukan bahwa para operator transportasi online belum seluruhnya menerima terhadap kebijakan pemerintah tersebut. Beberapa isi kebijakan yang di nilai memberatkan para pemiliki kendaraan yaitu mengenai STNK harus atas nama badan usaha dan pemebrian tanda khusus pada nomor rangka chasis agar dapat dilakukan revisi terhadap kebijakan tentang transportasi online.
\end{abstract}

\section{Kata Kunci, Angkutan Online}

\section{ABSTRACT}

This study aims to determine how high the response or the response of the online transport operators, namely; online transport driver, the owner of the vehicle, transport users online and Conventional Taxi Driver as well as managers of online transports, with regard to government policy 
online transport through Peraturan Menteri Perhubungan Nomor 32 Tahun 2016 Tentang Penyelenggaraan Angkutan Orang Dengan Kendaraan Bermotor Umum Tidak dalam Trayek.

This study method is based on qualitative research method by using a case study strategy and methods of descriptive analysis on each group of respondents through questionnaire instrument covered and analyzed the percentage of each question items presented graphically.

The results of this study found that online transport operators are not entirely receptive to the government policy. Some of the contents in the value of policies that burden the owner of the vehicle, the vehicle registration must be on behalf of a business entity and special award mark on chassis frame number in order to do a revision of the policy on transport on line.

\section{Keyword: Online Transport}

\section{PENDAHULUAN}

\section{A. LATAR BELAKANG}

Perkembangan transportasi di Indonesia semakin pesat seiring dengan akselerasi pembangunan yang menyeluruh dan berkelanjutan. Meningkatnya kapasitas infrastruktur transportasi terutama pada transportasi jalan semakin membuka terhadap wilayah terisolir dan meningkatkan pula mobilitas penduduk. Dengan demikian hampir secara merata di wilayah Indonesia bermunculannya wilayah baru dan daerah perkotaan kecil, sedang dan besar tumbuh dengan pesat. Bersamaan dengan peningkatan mobilitas penduduk tersebut baik di pedesaan, pinggiran kota dan di perkotaan telah meningkat pula permintaan atau kebutuhan sarana transportasi.

Berdasarkan survey pendahuluan terhadap beberapa pengguna Gojek maupun Grab Car, mereka sebagian besar berpendapat bahwa transportasi on line lebih murah dan cepat dalam memberikan pelayanan. Bahkan tidak hanya berfungsi sebagai angkutan penumpang tetapi juga bisa melayani angkutan barang dan pemesanan makanan. Fenomena booming transportasi on line, seperti yang telah dijelaskan diatas, menimbulkan protes para sopir Taxi konvensional. Penolakan tersebut diikuti demo besar besaran para sopir taksi dan angkutan umum di Jakarta beberapa waktu yanglalu. Oleh sebab itu untuk mengetahui secara lebih mendalam dampak yang ditimbulkan terhadap kinerja angkutan umum terutama taksi, perlu dilakukan penelitian secara seksama. Transportasi Online sebenarnya tidak dikenal dalam Terminologi Ilmu Transportasi Darat, Akan tetapi istilah tersebut muncul karena cara meletakan Komunikasi dengan sopir kendaraan yang di gunakan sebagai kendaraan Taxi menggunakan Smart Phone yang langsung Online. 


\section{B. RUMUSAN MASALAH}

1. Transportasi angkutan umum di Jakarta belum memberikan kepuasan terutama kenyamanan dan keamanan bagi para penggunanya.

2. Kemacetan lalu lintas di wilayah Jabodetabek menyebabkan masyarakat lebih memilih kendaraan pribadi atau dengan Go-Jek, Uber Taxi dan Grab- Bike.

3. Penolakan terhadap jenis angkutan umum seperti transportasi on line sempat menimbulkan gelombang demo yang anarkis oleh para sopir taxi non on line atau Taxi konvensional yang mengakibatkan penghasilan menurun.

4. Kebijakan transpostasi on line melalui Peraturan Menteri Nomor 32 Tahun 2016 Tentang Penyelenggaraan Angkutan Orang Dengan Kendaraan Bermotor Tidak Dalam Trayek sebagai upaya menyelesaikan masalah gejolak dalam masyarakat dengan kehadiran transortasi on line, secara empiristik belum tersosialisasikan secara efektif.

\section{PERTANYAAN PENELITIAN}

Berdasarkan rumusan masalah diatas, pertanyaan penelitian yang diajukan yaitu; apakah kebijakan mengenai Peraturan Menteri Perhubungan tersebut dapat dilaksanakan dan di patuhi oleh para operator online angkutan umum yaitu Sopir, pemilik kendaraan, pengelola Aplikasi ?

\section{TUJUAN PENELITIAN}

1. Mengetahui dan menganalisis penerapan layanan transportasi umum berbasis digital atau on line memiliki dampak terhadap kinerja pelayanan angkutan umum di Jakarta dan sekitarnya.

2. Mengetahui dan menganalisis Implementasi Kebijakan melalui Peraturan Menteri Perhubungan Nomor 32 Tahun 2016 Tentang Penyelenggaraan Angkutan Orang Dengan Kendaraan Bermotor Umum Tidak Dalam Trayek.

3. Mengetahui dan menganalisis tingkat kepatuhan para operator terhadap kebijakan mengenai transportasi on line di wilayah DKI Jakarta.

\section{METODE PENELITIAN}




\section{A. DESAIN PENELITIAN}

Penelitian ini merupakan penelitian "kualitatif" yang menurut Creswell (2003)) terdapat lima strategi dalam penelitian kualitatif yaitu; narratives, phenomenologis, ethnographis, ground theory dan case study. Penelitian mengenai "layanan transportasi umum berbasis teknologi digital atau on line lebih tepat jika jenis penelitian dilakukan yakni sebagai penelitian "studi kasus" atau case study". Dalam penjelasan lebih lanjut Creswell mengatakan bahwa; dalam penelitian jenis studi kasus dimana keterlibatan peneliti sangat mendalam dalam mengungkapkan fenomena agar dapat memberikan pemahaman secara komprehensif. Adapun penelitian kualitatif dengan jenis "studi kasus" memiliki panduan atau pedoman agar proses penelitian lebih cermat dan hasilnya akurat. Pedoman tersebut menurut Stake dalam Norman K Denzin and Yvonna S Lincoln (1994) yaitu pertama; peneliti harus membatasi kasus yang akan diteliti. Kedua; peneliti harus menyeleksi fenomena, tema atau isu yang akan menjadi pertanyaan penelitian. Ketiga; peneliti mencari pola dari data yang terhimpun untuk membentuk isu isu yang sesuai dengan pertanyaan penelitian. Keempat ; penelitiharus menerapkan trianggulasi sebagai kunci pengamatan dan dasar untuk intepretasi. Kelima; peneliti menyeleksi alternative interpretasi yang akan digunakan untuk membangun pernyataan umum tentang kasus atau kesimpulan penelitian. Berdasarkan uraian diatas dalam penelitian mengenai layanan transportasi umum berbasis teknologi digital atau on line sedapat mungkin mengikuti pedoman yang diutarakan para pakar diatas. Penelitian ini mengenai studi kasus Transportasi Online terkait dengan pelaksanakaan Peraturan Menteri Perhubungan Nomor 32 Tahun 2016 Tentang Penyelenggaraan Angkutan Orang Dengan Kendaraan Bermotor Umum tidak dalam Trayek.

\section{B. PENGUMPULAN DATA}

Dari hasil pengumpulan data yang diperoleh yaitu berupa data primair dan data skundair. Data primair yaitu data yang diperoleh langsung dari lapangan atau obyek penelitiaan dengan menggunakan instrument questioner terhadap responden yang terpilih dan dilengkapi dengan wawancara yang mendalam terhadap suatu fenomena atau kasus yang menjadi obyek penelitian. Disamping itu juga menggali infomasi kepada beberapa key informan yang dianggap memahami obyek penelitian secara mendalam. Adapun data skundair yaitu data yang diperoleh dari instansi pemerintah atau lembaga penelitian dan asosiasi profesi yang sudah diolah dan tinggal disajikan sesuai dengan relevansi tujuan penelitian. Adapun dipilih sebagai responden untuk menjaring informasi mengenai Pelaksanaan Peraturan Menteri 
Perhubungan Nomor 32 Tahun 2016 Tentang Penyelenggaraan Angkutan Orang Dengan Kendaraan Bermotor tidak dalam trayek umum yaitu; para pengguna transportasi on line dan sopir taxi, pengendara trayek memilih kendaraan transportas Online dan para pengelola Grab Car.

Jumlah Responden seluruhnya sebanyak 110 (seratus sepuluh) orang yang terbagi dalam kategori respondent, Pemilik Kendaraan (25) Pengemudi di Transportasi Online (25), Pengguna Transportasi Online (25 orang), Pengelola Transportasi Online (10 orang), sopir taxi (25 orang),

\section{METODE ANALISIS}

Jenis penelitian ini termasuk penelitian kualitatif maka metode analisis berupa penjelasan secara lebih detail terhadap aspek aspek yang merupakan fenomena dan menjadi focus atau obyek penelitian. Uraian penjelasan yang rinci harus memenuhi unsur logis dan sistimatis serta komprehensif. Analisis Diskriptif terhadap Pilihan Jawaban responden yang terkait dengan pelaksanaan Pelaksanaan Menteri Perhubungan Nomor 32 Tahun 2016.Untuk mendapatkan Informasi yang cukup melalui Question tertutup

\section{KELUARAN ATAU OUTPUT}

Pada tahap akhir dari seluruh proses penelitian menghasilkan beberapa temuan mengenai.

1. Respon para pemilih dan Operator Transportasi Online menerima atau menolak kebijakan Peraturan Menteri Perhubungan nomor 32 Tahun 2016.

2. Konten atau isi Peraturan Menteri mana yang menjadi keberatan atau penolakan oleh para operator Transportasi Online.

3. Kesiapan Pemerintah Dalam Pelaksanaan kebijakan Peraturan Menteri Pehubungan Nomor 32 Tahun 2016.

\section{A. TRANSPORTASI ON LINE BERBADAN HUKUM}

Peraturan mengenai legalitas transportasi on line akan diberlakukan bahwa bagi para pemilik kendaraan yang digunakan sebagai transportasi on line harus diwadahi oleh lembaga yang berbagadan hukum. Bentuk badan hukum tersebut yaitu antara lain BUMN/ BUMD, Perseroan Terbatas (PT) dan Koperasi. Seperti yang disampaikan oleh Ridzki Kramadibrata Managing Director Grab Indonesia mengatakan "mereka akan membuat koperasi sebagai wadah Grab Car. Ini merupakan salah satu solusi yang sedang mereka tempuh demi 
mengatasi masalah legalitas yang belakangan menjadi kontroversi”. Sekarang kami sedang mengurus pembentukan koperasi. Saat ini Grab Car masih ada pengemudi pribadi, ada juga yang sudah rental. Koperasi rencananya untuk menaungi yang pribadi. Apakah bentuk koperasi tunggal atau terdiri dari beberapa koperasi, masih belum diputuskan. Kami ikut saja apa yang nanti diputuskan pemerintah. Sedang menurut Menteri Kominfo Rudi Antara ketika dimintai komentar oleh media massa mengatakan " meskipun ia sudah menerima surat pemblokiran dari Menteri perhubugan, terhadap transportasi on line, namun masih meikirkan solusi lain sambil duduk bersma dengan para pemilik aplikasi. Salah satu solusi yaitu megajak bekerjasama dengan Menteri Koperasi Anak Agung Geda Puspayoga untuk membat kedua layanan tersebut memiliki koperasi yang mewadahi pengemudi pengemudi pribadi didalamnya". Disamping itu Uber juga sudah berusaha untuk membuat wadah koperasi untuk mewadahi para pengemudi Uber yang masih menggunakan kendaraan pribadi. Menurut juru bicara Uber di Indonesia Army Kunrojpanya yang menulis dalam blog resmi Uber yaitu " hari ini dengan gembira kamim umumkan bahwa mitra Uber yaitu Koperasi Jasa Trans Usaha Bersama telah memperoleh akte pendirian koperasi.

\section{B. JUMLAH ARMADA TRANSPORTASI ONLINE DI JAKARTA TAHUN 2015}

\begin{tabular}{|c|c|c|c|c|c|c|c|c|}
\hline No & $\begin{array}{c}\text { Operator } \\
\text { Transporta } \\
\text { s Online }\end{array}$ & Jumlah & $\begin{array}{c}\text { Jumlah yang } \\
\text { kendaraan } \\
\text { Uji KIR }\end{array}$ & $\%$ & $\begin{array}{c}\text { Kendaraan } \\
\text { Lulus Uji } \\
\text { KIR }\end{array}$ & $\begin{array}{c}\text { Kendaraan } \\
\text { yang tidak } \\
\text { Lulus }\end{array}$ & $\%$ & Keterangan \\
\hline 1 & 2 & 3 & 4 & 5 & 6 & 7 & 8 & 9 \\
\hline 1 & UBER & 8.000 & 127 & $\begin{array}{c}1,58 \\
\%\end{array}$ & 116 & 11 & 8,6 & \\
\hline 2 & GRAB & 5.000 & 174 & $\begin{array}{c}3,48 \\
\%\end{array}$ & 153 & 21 & 12 & \\
\hline & & & & & & & & \\
\hline
\end{tabular}

Sumber ; M.Liputan 6.com

Data diatas masih terbatas pada Transportasi Online yang dikelola oleh Uber dan Grab. Jumlah keseluruhan Armada sebanyak 13.000 armada. Adapun armada yang telah 
mengikuti uji KIR kendaraan bermotor hanya berjumlah 301 kendaraan atau 5,06\% sekarang yang lulus KIR sebanyak 269 atau 39,36\%.

\section{INVENTARISASI PELANGgARAN TRANSPORTASI ONLINE TERHADAP PERATURAN PERUNDANG PERUNDANG-UNDANGAN BIDANG LLAJ dan PERUNDANGAN PERMULANGAN LAIN YANG TERKAIT.}

Seperti diketahui bahwa kehadiran "transportasi on line" menghebohkan masyarakat Jakarta dan sekitar serta di beberapa kota besar lainnya. Kontroversi tersebut disebabkan "Transportasi online" seperti Go-jek, Go Car, Grab Bike, Grab Bike, Grab Can dan Uber Sesunguhnya transportasi online telah melanggar Peraturan Pemerintah di Bidang LLAJ, akan tetapi angkatan orang yang popular dan digemari masyarakat Jakarta dan sekitarnya. Pada kenyataan nya kehadiran "Transportasi on line" ada pihak yang merasa dirugikan yaitu para sopir Taxi konvensional dan sopir angkutan umum lainnya yang merasakan pendapatannya terus menurun. Bahkan sempat menimbulkan gejolak sosial melalui demonstrasi besar-besaran di Jakarta dalam Surat Menteri Perhubungan Nomor AJ/2006/1/1PHB 2016 tanggal 14 Maret 2016 ditujukan kepada Menteri Kominfo yang isinya agar Menteri Kominfo memblokir kedua Aplikasi Uber dan Grab. Menurut Menhub daftar panjang pelanggaran kedua aplikasi tersebut yaitu sebagai berikut :

1. Aplikasi Uber dan Grab dianggap melanggar Undang-Undang Nomor 22 Tentang Lalu Lintas Angkutan Jalan, Undang-Undang Nomor 6 Tahun 1983 Ketentuan Umum dan Tatat cara Perpajakan dan Undang Undang Nomor 25 Tahun 2007 tentang Penanaman Modal.

2. Dinilai melanggar Keputusan Presinde RI Nomor 90 Tahun 200 Tentang Perwakilan Perusahaan Asing dan Peraturan Pemerintah Nomor 82 Tahun 2012 Tentang Penyelenggaraan Sistem dan Transaksi Elektronik.

3. Menurut surat Kemenuhb khusus Uber Star Up tersebut melanggar; pelanggaran terhadap pasal 139 ayat 4 UU Nomor 22 Tahun 2009 tentang Lalu Lintas Angkutan Jalan, bahwa penyediaan jasa angkutan umum dilaksanakan oleh Badan Usaha Milik Negara, Badan Usaha Milik daerah dan atau badan hukum lain sesuai ketentuan peraturan perundang-undangan. Kemudian pelanggaran terhadap. Kemudian pelanggaran terhadap pasal 173 ayat 1 UU Nomor 22 Tahun 2009 Tentang Lalu Lintas Angkutan Jalan bahwa usaha angkutan umum yang menyelenggaraan angkutan dan atau barang wajib izin penyelenggaraan angkutan. Pelangaran terhadap pasal 5 ayat 
2 UU Nomor 25 Tahun 2007 Tentang Openanaman Modal bahwa penanaman modal asing wajib wajib dalam bentuk perseroan terbatas berdasarkan hukum Indonesia dan berkedudukan di dalam wilayah Negara Republik Indonesia kecuali ditentukan oleh undang-undang.

4. Mash menyangkut Uber, dianggap melanggar Keputusan Presiden Republik Indonesia nomor 90 Tahun 2000 Tentang Kantor Perwakilan Perusahaan Asing (KPPA) dan Surat Keputusan Kepala BPKM Nomor 22 Tahun 2001 bahwa Uber Asia Limited sebagai KPPA sesuai dengan Pasal 2 Keputusan Kepala BKPM Nomor 22 Tahun 2001, dan KPPA tidak diperkenankan melakukan kegiatan komersial, termasuk transaksi jual beli barang dan jasa di Indonesia dengan Perusahaan atau perorangan serta tidak akan sulit serta dalam bentuk apapun dalam pengelolaan suatu perusahaan, anak perusahaan, atau cabang perusahaan yang ada di Indonesia.

5. Uber dan Grab dinilai tidak bekerjasama dengan perusahaan angkutan umum yang resmi tetapi dengan perusahaan illegal atau peroraongan.

6. Keberadaaan Uber dan Grab menimbulkan keresahan dan konflik di kalangan pengusaha angkutan resmi dan pengemudi taxi resmi.

7. Kebereadaan Uber dan Grab berpotensi semakin menyuburkan praktek angkutan (illegal) sementara angkutan umum tidak diminati.

\section{PEMBAHASAN HASIL PENELITIAN}

Penelitian ini telah menghasilkan temuan yang terkait dengan pelaksanaan kebijakan tentang Peraturan Menteri Perhubungan Nomor 32 Tahun 2016 tentang Penyelenggaraan Angkutan Orang Dengan Kenderaan Bermotor Umum Tidak Dalam Trayek.

Temuan tersebut antara lain mengenai respon para operator transportasi online yang terdiri dari pengemudi transportasi online, pemilik kenderaan pengguna transportasi online, pengelola transportasi online dan pengemudi taxi konvensional.

Adapun respon para operator transportasi online tersebut digali melalui daftar pertanyaan tertutup terhadap operator transport online sebagai berikut.

Tanggapan secara umum dari hasil survey terhadap sampel sopir transportasi on line seperti pada penyajian diatas yaitu $60 \%$ sebagai mantan sopir taxi dan $40 \%$ bukan dari sopir taxi. Data tersebut menunjukan bahwa ada perpindahan yang cukup signifikan dari sopir taxi konvensional beralih ke sopir transportasi on line. Ketika ditanyakan alasannya kepada 
mereka mengatakan bahwa $48 \%$ penghasilnya lebih besar, $32 \%$ mengatakan tidak dikejar setoran dan 20\% mengatakan lebih bebas. Data tersebut menunjukan bahwa jenis transportasi on line pada dasarnya memiliki suasan yang berbeda dengan ketika mereka bekerja sebagai sopir taxi konvensional. Alasan yang dikemukakan seperti telah disebutkan diatas, artinya bahwa cara pengelolaan transportasi on line dengan apilkasi smartphone disamping praktis dalam pemberian pelayanan dan juga dengan kendaraan yang lebih nyaman dan lebih berbau privacy.

Selanjutnya ketika ditanyak mengenai pengetahuan implementasi kebijakan Menteri Perhubungan tentang Permenhub nomor 32 tahun 2016. Ketika ditanyakan apakah mengetahui mengenai kebijakan tersebut jawaban mengetahui kebijakan tersebut sebesar $84 \%$, artinya sebagian besar sopir on line mengetahui adanya kebijakan tersebut. Rasionalitas besarnya respon terhadap kebijakan tentang transportasi on line dikarenakan mereka berkepentingan dengan maksud dan tujuan kebijakan transportasi online terkait dengan nasib perkejaannya. Boleh jadi mereka khawatir jika kebijakan tersebut tidak atau kurang menguntungkan mereka sebagai sopir transportasi on line.

Kemudian ketika pertanyaan dilanjutkan mengenai sumber informasi kebijakan mereka menjawab sebesar $70 \%$ sumber infomasi dari teman teman sesame sopir, sedangkan $20 \%$ dari surat kabar dan $10 \%$ dari televise. Data tersebut menunjukan informasi melalu teman kerja bisa diartikan salurannya melalui telpon, sms atau whatshap, karena dewasa ini sarana tersebut sudah dimiliki oleh berbagai lapisan masyarakat. Artinya saluran komunikasi masyarakat dalam kehidupan sehari hari telah mengikuti perkembangan teknologi infokrmasi.

Selanjutnya ketika ditanyakan alasan tidak setuju terhadap kebijakan tersebut diperoleh jawaban sebesar $75 \%$ merugikan pemilik kendaaraan bemotor, $15 \%$ takut kehilangan pekerjaan dan $10 \%$ menjawab tidak tahu. Berdasarkan data tersebut menunjukan bahwa sebagian besar para sopir jika kebijakan mengenai taransporasi on line yaitu takut kehilangan pekerjaan, jika dikaitkan dengan pemilik kendaraan manarik kendaraannya untuk tidak dioperasikan sebaga transportasi on line.

Kemudian ketika diajukan pertanyaan mengenai pemahaman isi peraturan perundangan yang akan diterapkan mengatur operasi angkutan melalui on line yaitu; memberlakukan uji KIR bagi kendaraan transportasi on line sebesar $40 \%$, STNK kendaraan atas nama perusahaan sebesar $35 \%$ dan setiap pengusahaan terhadap kendaraan transportasi on line harus berbadan hukum yaitu sebesar $25 \%$. Berdasarkan data diatas menunjukan bahwa pengetahuan 
mengenai isi peraturan menteri tersebut hanya berkisar tiga (3) hal seperti yang disebutkan diatas. Barangkali cukup masuk akal jika pengetahuan para sopir hanya terbatas pada materi tersebut. Padahal isi peraturan menteri cukup banyak mengatur transportasi on line. Barangkali tiga hal diatas yang paling sering di bicarakan oleh para sopir setiap kai mereka membahas mengenai kebijakan menteri operhubungan. Memang ketiga hal tersebut terkait dengan nasib mereka yakni jika pemilik kendaraan berkeberatan dengan peraturan tersebut dan menarik kendaraan dari operasi transportasi on line maka para sopir akan kehilangan pekerjaanya.

Selanjutnya pertanyaan mengenai respon setuju atau tidak setuju terhadap kebijakan pemerintah tersebut maka yang menyatakan setuju $80 \%$ sebagian peraturan dan $10 \%$ tidak setuju seluruhnya dan sisanya $10 \%$ menjawab tidak tahu. Artinya meskipun yang menyatakan setuju mencapai $80 \%$ akan tetapi hanya setuju sebagian saja dari isi kebijakan pemerintah tersebut, Dengan demikian $80 \%$ responden juga tidak menyetujui sebagian isi aturan dari kebijakan tersebut antara lain mengenai; kendaraan harus atas nama perusahaan, pemberian tanda khusus pada mesin kendaraan, stiker yang ditempelkan pada kendaraan tersebut.

Kemudian ketika ditanyakan mengenai isi Permen mana yang tidak disetujui maka $80 \%$ mengatakan tidak setuju jika kendaraan diatas namakan perusahaan. Adapun yang menjawab tidak setuju berbadan hukum hanya $10 \%$ dan tidak setuju dengan Uji KIR $10 \%$. Artinya sebagian besar pengemudi transportasi online tidak setuju kendaraan atas nama perusahaan di karenakan kemungkinan bahwa pengemudi takut kehilangan pekerjaan. Jika peraturan tersebut diterapkan maka pemilik kendaraan akan menarik kendaraan yang sudah di operasikan oleh pengemudi tersebut.

Terkait dengan pertanyaan di atas maka pada pertanyaan selanjutnya ketika ditanyakan alasan tidak setuju ada korelasinya dengan pernyataan para pengemudi diatas. Alasan para pengemudi tidak menyetujui isi peraturan menteri tersebut $75 \%$ mengatakan bahwa dengan ditetapkan peraturan-peraturan diatas akan merugikan pemilik kendaraan, sedangkan alasan takut kehilangan pekerjaan sebesar 15\% selanjutnya jawaban $10 \%$ adalah tidak tahu. Artinya bahwa para pengemudi pada prinsipnya ketika pemilik kendaraan tidak dapat melaksanakan kebijakan pemerintah tersebut sebagai konsekuensinya kendaraan akan ditarik atau tidak di operasionalkan. 
Selanjutnya berdasarkan data yang disajikan dibawah ini yaitu mengenai respon para pemilik kendaraan transportasi on line. Adapun data yang diperoleh berdasarkan penggunaan instrumen pertanyaan tertutup yaitu sebnagai berikut ;

Jika ditanyakan mengenai pengetahuan kebijakan transportasi on line memberikan jawaban yang sebenarnya tidak lazim dalam penelitian yakni jawaban mencapai 100\%. Para Pengguna memang sebagian besar berpendidikan tinggi sehingga selalu tidak ketinggalan mengikuti perkembangan informasi. Apalagi terkait dengan transportasi on line menyangkut kepentingan pribadinya. Dengan demikian masing masing pemilik kendaraan selalu mengikuti perkembangan yang terjadi di lapangan maupun terhadap perubahan kebijakan pemerintah. Artinya para pemilik kendaraan sangat sensitif terhadap setiap perubahan kebijakan atau tindakan pemerintah terhadap transportasi on line yang pada prinsipnya melanggar peraturan perundangan di bidang Lalu Lintas Angkutn Jalan. Oleh sebab itu cukup logis jika semua pemilik kendaraan mengetahui adanya kebijakan transportasi on line yang baru tersebut.

Demikian pula ketika pertanyaan berikutnya disampiakn mengenai sumber informasi peratauran tersebut secara umum mengatakan $50 \%$ bersumber dari surat kabar dan internet, $40 \%$ dari televise serta $10 \%$ bersumber dari teman. Oleh karena para pemiliki rata rata memiliki pendidikan yang tinggi dalam memilih dan mengakses informasi sebagian besar dar surat kabar bahkan internet atau televisi. Salah sati ciri masyarakat yang terdidik mencari informasi bersumber dari ketiga media tersebut diatas.

Adapun seberapa jauh pengetahuan para pemilik kendaraan transportasi on line terhadap kebijakan tersebut. Jawaban respoden yang mengatakan telah membaca sebagian atau sekilas dibaca yang pokok pokok cukup besar yaitu mencapai $65 \%$, sedang telah membaca seluruhnya mencapai $25 \%$ dan yang belum membaca sebanyak $10 \%$. Sebenarnya para pemilik kendaraan transportasi on line sangat berkaitan dengan permasalahan kebijakan transportasi on line. Namun ketika ditelusuri kepedulian para pemiliki kendaraan terhadap kebijakan tersebut terkait dengan kepentingan atau kebutuhannya agar keberadaan transportasi on line tetap bis dipertahankan. Artinya dengan kata lain keberadaan transportasi on line sudah menjadi kebutuhan bahkan kepentingan dasar kehidupan sehari hari atau dengan kata lain telah menjadi mata pencahariannya.

Selanjutnya ketika ditanyakan keberatan terhadap kebijakan menteri perhubungan tersebut yang menjadi keberatan sebanyak $72 \%$ terhadap aturan yang menetapkan bahwa STNK 
kendaraan transportasi on line harus tertulis atas nama perusahaaan atau berbadan hukum. Artinya bahwa penolakan terhadap aturan yang dianggap memberatkan pemilik kendaraantersebut.

Selanjutnya mengenai tingkat kepatuhan terhadap kebijakan pemerintah sebanyak $40 \%$ akan mentaati atau mematuhi peraturan tersebut, $30 \%$ ragu ragu dan $30 \%$ belum bersikap . Berdasarkan data tersebut yang siap mematuhi hanya $40 \%$, artinya sisanya $60 \%$ antara ragu ragu dan belum bersikap mencerminkan penolakan secara halus. Akan tetapi jika di lihat secara komprehensif maka konten aturan yang mendapat penolakan yaitu ; kendaraan transportasi on line harus atas nama perusahaan dan bukan atas nama pribadi serta pemberian kode khusus pada rangka mesin. Adapun konten atau isi aturan yang lain mereka siap mematuhi kebijakan tersebut. Artinya para pemilik kendaraan menghendaki perubahan kebijakan yang terkait dengan isi aturan yang menjadi keberatan diatas . Namun sebenarnya jika seluruh kendaraan kepemilikannya oleh beberapa orang yang tergabung dalam suatu badan usaha, aturan yang menjadi keberatan diatas akan lebih mudah diterapkan secara kelembagaan dibanding sifat kepemilikan oleh orang per orang. Oleh karena transportasi on line secara umum kepemilikan lebih banyak bersifat pribadi maka untuk menerapkan aturan tersebut menghadapi kendala yang cukup dilematis.

Kemudian ketika ditelusuri mengenai pemahaman yang mendalam isi kebijakan secara menyeluruh kurang merespon dari para pemilik kendaraan karena sosialisasi kebijakan tersebut belum menyelurh terhadap sasaran kelompok atau target groupnya. Sebanyak 70\% belum pernah mengikuti sosialisasi yang diselenggrakan pemerintah yang terkait, yng pernah ikut sosialisasi hanya $10 \%$ dan $20 \%$ menjawab tidak tahu.

Selanjutnya ketika ditanyakan apa keinginan mereka terhadap kebijakan pemerintah, para pemilik kendaraan yang menghendaki revisi peraturan tersebut seusuai yang menjadi keberatan sebanyak $80 \%$, sedang sebanyak $10 \%$ ragu ragu dan $10 \%$ menjawab tidak tahu.

Informasi yang diperoleh dari responden pengguna jasa transportasi on line sebanyak 25 yaitu yang rata pernah menggunakan transportasi on line dalam melakukan kegiatan sehari hari frekuensi $10 \mathrm{X}$ sebanyak 52\%, frekuensi $20 \mathrm{X}$ sebanyak $20 \%$, frekuensi diatas $20 \mathrm{X}$ sebanyak $16 \%$ dan sebanyak $12 \%$ frekuensi $5 \mathrm{X}$ dalam menggunakan transportasi on line. Berdasarkan data tersebut maka karakteristik responden dalam hal menggunakan jasa 
transportasi on line sebagian besar memang menjadi rutinitas sehingga kketika menggali informasi mengenai kebijakan transportasi on line cukup representative.

Ketika ditelusuri lebih lanjut mengenai dorongan atau motivasi menggunakan transportasi on line 70\% mengatakan "murah dan nyamana", $25 \%$ menjawab cepat dan nyaman", sedangkan yang 5\% tidak menjawab. Artinya bahwa sebagian besar pengguna transportasi on line mersakan adanya perbedaan yang signifikan antara pelayanan transportasi on line dengan pelayanan Taxi konvensional. Disamping lebih murah dan juga pemesanan bisa dilakukan dimana pengguna berada dalam waktu lima menit atau sepuluh menint. Pelayanan lebih nyaman karena kendaraan layaknya seperti milik pribadi dengan sopirnya.

Para pengguna transportasi on line juga menyampaikan bahwa disamping nyaman dan aman juga sebagian besar pengguna 90\% selama ini belum mengalami kejadian kriminal dan hanya $10 \%$ pernah mengalami kejadian yang kurang menyenangkan. Ketika diperdalam mengenai kejadian tidak menyenangkan antara lain ; sopir tidak memberikan informasi pada saat pemesanan bahwa ternyata transportasi on line jenis ini disebut "Uber $X$ " artinya selama dalam perjalanan dapat menaikan penumpang lain yang pesan berikutnya. Disamping itu kesalahan informasi atau misinformasi dalam pemesanan ternyata tercatat lokasi lebih jauh sehingga tarifnya lebih mahal.

Kemudian ketika pengguna transportasi on line ditanyakan respon responden terhadap keberadaan trasnportasi on line melanggar peraturan perundangn bidang LLAJ sebanyak $70 \%$ mereka mengetahui bahwai transportasi on line, $20 \%$ hanya mnedengar saja dari orang lain dan $10 \%$ mengatakan tidak tahu. Artinya bahwa pengguna transportasi on line yang sebagian besar orang terdidik menunjukan bahwa mereka mengikuti perkembangan adanya perubahan di sekitarnya. Meskipun mengetahui transportasi on line sebagai pelanggaran akan tetapi para pengguna masih terus menggunakan transportasi on line dalam melakukan kegiatannya. Artinya bahwa para pengguna tidak terlalu mempedulikan terhadap pelanggaran tersebut, dan para pengguna lebih cenderung bersifat pragmatis.

Meskipun para pengguna tidak mempersoalkan adanya pelanggaran kendaraan yang ditumpangi akan tetapi para pengguna cukup peduli dengan adanya kebijakan tentang transportasi on line. Terbukti ketika ditanyakan mengenai kebijakan transortasi ion line 
yang mengetahui adanya peraturan tersebut yakni sebesar 60\% mengetahui adanya kebijakan tersebut, sedang 30\% menyatakan pernah mendengar dan $10 \%$ mengatakan tidak tahu. Artinya bahwa kebijakan cukup diketahui oleh pengguna merupakan bentuk kesadaran hukum masyarakat meskipun tidak terkait langsung. Dengan demikian boleh jadi jika transportasi on line dilarang beroperasi maka para pengguna akan merasa dirugikan kepentingannya.

Pengetahuan yang cukup para pengguna transportasi on line ternyata memiliki pengaruh terhadap respon positip adanya kebijakan pemerintah tentang transportasi on line. Sebanyak 90\% setuju terhadap kebijakan pemeritah, sedang $10 \%$ kurang setuju. Artinya dengan tingkat dukungan yang tinggi terhadap kebijakan pemerintah untuk mengatur transportasi on line supaya berjalan lebih tertib dan terjamin keamanannya serta dilindingi oleh pemerintah. Selanjutnya ketika ditanyakan alasan setuju, para pengguna memberikan jawaban yang cukup beragam yaitu; $50 \%$ menjawab agar transportasi on line keberadaanya diakui pemerintah, sedang yang lain sebanyak $20 \%$ untuk mengurangi gejolak sosial, adapun sebanyak $20 \%$ agar lebih tertib dan teratur kemudian 10\% untuk keselamatan transportasi. Artinya bahwa para pengguna memiliki kpercayaan yang cukup tinggi bahwa keberadaan transportasi on line bisa dipertahankan terus karena dianggap membantu mereka dalam melakukan aktifitas sehari dengan praktis dan nyaman serta lebih murah. Adapun aspek yang lain juga menjadi perhatain para pengguna antara lain; tertib dan teratur, keselamatan transportasi dan mengurangi gejolak sosial. Keberagaman alasan yang disampaikan oleh para pengguna transportasi on line menunjukan bahwa pda dasarnya transportasi umum memiliki dimensi sosial yang harus terintegrasi dalam pembinaannya oleh pemerintah sebagai pemangku kepentingan.

Selanjutnya penelitian juga memasukan kelompok respoden pengemudi atau supir Taxi konvensional. Informasi yang dibutuhkan ingin mengetahui respon mengenai kebijakan pemerintah dalam mengatur transportasi on line karena selama ini ditolak kehadirannya berdampak berkurang pernghasilannya. Keterkaitan tersebut menjadi alas an bahwa sopir Taxi konvensionallayak menjadi salah satu kelompok responden. Adapun informasi yang diperoleh dengan menggunakan questioner tertut yaitu sebagai berikut;

Informasi awal yang diperlukan yaitu mengenai masa kerja menjadi sopir Taxi konvensional 
Yaitu yang memiliki masa kerja 5 tahun sebanyak 20\%, maksimal 10 tahun sebanyak $35 \%$, sedang yang memiliki maksimal 15 tahun 35\% dan diatas 15 tahun 10\%. Artinya bahwa para sopir atxi tersebut memiliki masa kerja yang cukup bervariasi mulai dari 5 tahun sampai diatas 15 tahun.

Selanjutnya ketika ditanyakan penghasilan sehari antara Rp. 100.000 s/d 150.000 sebanyak 60\%, sedang yang berpeghasilan Rp. 150,000 s/d Rp.200.000 sebanyak $32 \%$ dan sisanya berpengahasilan Rp. 50.000 s/d Rp. 100.000 sebanyak 8\%. Artinya bahwa para pengemudi taxi kovensional sebanyak $92 \%$ penghasilan diatas Rp.100.000. Pada umumnya penghasilan tersebut sebagai penghasilan bersih. Penghasilan tersebut disampaikan sebelum beroperasinya transportasi on line di DKI Jakarta. Namun jika ditanyakan penghasilan saat ini setelah beroperasi transportasi on line, penghasilannya menurun.

Seperti diketahui bersama bahwa sopir Taxi konvensional yang paling dirugikan dengan adanya transportasi on line. Pada waktu demontrasi besar besaran di Jakarta sebagian besar pesertanya adalah sopir taxi. Oleh sebab itu ketika ditanyakan bahwa transportasi on line itu melanggar peraturan perundangan maka sebanyak $90 \%$ mereka menjawab tahu dan $10 \%$ tidak tahu.

Terkait dengan pertanyaan diatas mengenai penghasilan, ketika ditanyakan berapa besar pengaruh transportasi on line terhadap penghasilan sekarang, yang menjawab turun antara $50 \%$ s/d $60 \%$ sebanyak $60 \%$, sedang yang menjawab 30\% s/d \% 50\% sebanyak 32\&, sedang yang mengatakan pernghasilan menurun $60 \%$ ke atas, adapun yang penghasilan menurun tajam yaitu $60 \%$ keatassebabnyak $8 \%$, Penurunan yang cukup tajam baik yang kelompok turun $60 \%$ maupun yang kelompok turun $32 \%$ maka mereka mencari pekerjaan lain atau pindah menjadi sopir transportasi on line. Indikasi penurunan penghasilan taxi konvesional yaitu ; di beberapa pool taxi ratusan mobil tahun parkir tidak beroperasi dan banyak sopir transportasi on line berasal dari sopir taxi konvensional.

Terkait dengan pengetahuan para sopir taxi konvensional mengenai transportasi on line yang telah melanggar peraturan perundangan, ketika ditanyakan banwa para sopir tai juga telah mengetahui adanya kebijakan pemerntah yang mengatur seputar transportasi on line guna mengatur dan menertibkan transpostasi on line. Oleh sebab ituketika ditansyakan peraturan menteri awai tersebut, maka sebanyak $80 \%$ tahu dari teman dan sisanya $20 \%$ dari media massa. Artinya komunikasi antar sesama sopir bagi mereka cukup efektif sebagai penyampai 
pesan termasuk ketika mereka saling tukar informasi mengenai kebijakan pemerintah yang mengatur transportasi on line.

Demikian pula ketika ditanyakan apakah saudara setuju dengan kebijakan pemerintah tersebut, mereka menjawa sangat setuju $70 \%$ dan setuju $20 \%$ sedang yang menjawab tidak tahu $10 \%$. Artinya bahwa mereka pada dasarnya tidak menghendaki adanya transportasi on line. Oleh sebab itu mereka berharap pemerintah mengatur dengan adil transportasi on line yang selama ini masih dianggap melanggar peraturan perundangan di bidang Laku Lintas Angkuta Jalan.

Adapun alasan yang disampaikan oleh sopir taxi setuju terhadap kebijakan pemerintah yang mengatur transportasi on line supaya ditertibkan sebanyak $80 \%$ dan mengurangi gejolak social sebanyak $20 \%$. Artinya para sopir taxi mendukunga terhadap kebijakan pemerintah bahwa pelaksanaan kebijakan tersebut diharapkan dapat berjakan dengan baik.

Meskipun mereka tahu dan setuju adanya kebijakan pemerintah akan tetapi banyak yang tidak tahu mengenai isi dari kebijakan pemerinah yaitu Permen Nomor 32 Tahun 2016, sebagian besar yaitu sebanyak $80 \%$ mengatakan tidak tahu isi peraturan menteri tersebut.

\section{Kesimpulan}

- Para responden yang terdiri dari pengemudi transportasi online, pengguna jasa, pemilik kendaraan dan supir taxi konvensional mengetahui adanya Peraturan Menteri Perhubungan Nomor 32 Tahun 2016 tentang Penyelenggaraan Angkutan Orang Dengan Kendaraan Bermotor Umum Tidak Dalam Trayek.

- Pengetahuan mengenai isi peraturan menteri perhubungan nomor 32 tahun 2016 sebagian besar hanya responden pemilik kendaraan bermotor dan sebagian kecil para pengemudi

- Isi peraturan yang menjadi keberatan bagi pemilik kendaraan yaitu balik nama STNK dan BPKB atas nama perusahaan atau badan hukum dan pemberian tanda khusus terhadap nomor angka chasis serta penempelan stiker.

- Para responden terutama pengemudi dan pemilik kendaraan belum banyak mendapatkan sosialisasi tentang isi dari permenhub tersebut

- Kehadiran transportasi online sangat berpengaruh terhadap penghasilan sopir taxi konvensional

- Pemilik kendaraan berharap permenhub tersebut tidak memberatkan dalam pengoperasian transportasi online 
- Pada prinsipnya adanya permenhub akan ditaati dan dipatuhi, kecuali yang menjadi keberadaan para pemilik kendaraan transportasi online

\section{Saran}

- Perlu dialukan sosialisasi yang lebih itensif mengenai Peraturan Menteri Perhubungan Nomor 32 Tahun 2016 tersebut.

- Aspirasi para operator transportasi online agar diakomodir dalam peraturan menteri tersebut terutama yang menjadi keberatan para pemilik kendaraan transportasi online.

\section{DAFTAR PUSTAKA}

Creswell, John,2003, Reseach Design Qualitative and Quantitative and Mixed Approaches, Second Edition, Thousand Oak, London; New Delhi, Sage Publication.

Denzin, Norman K and Yvonna S Linconln, 1994, Hand Book Of Qualitative Research, Thousand Oak London. New Delhi, Sage Publications

Hook, Walter, 2005, Institutional and Regulatory Options For Bus Rapid Transit In Developing Countries, ITDP,p.3

Istianto, Bambang, 2011, Manajemen Pemerintahan Dalam Perspektif Pelayanan Publik, Penerbit. Mitra Wacana Media, Jakarta.

Jamal. Irzal dan Deddy Arief, 2002, Kebijaksanaan Pelayanan Angkutan Perkotaan dan Penerapannya, Di DKI Jakarta, h,10

White, Peter, 1995, Public Transport Its Planning, Management and Operation, UCL, Press, London.

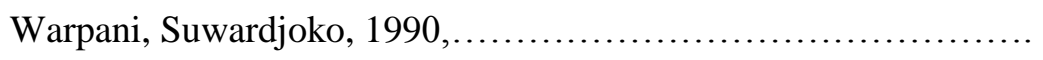

Undang Undang Nomor 22 Tahun 2009 Tentang Lalu Lintas Angkutan Jalan

Peraturan Pemerintah Nomor 74 Tahun 2014 Tentang Angkutan Jalan

Peraturan Menteri Perhubungan Nomor 32 Tahun 2016 Tentang Penyelenggaraan Angkutan Orang Dengan Kendaraan Bermotor Umum Tidak Dalam Trayek

www.bbc.com>indonesia 27 April 2016

tekno.kompas.com > Business tanggal 20 April 2016

economy.okezone.com tanggal 23 September 2015

kompas.com 16 Maret 2016

kompas.com 21 maret 2016

kompas.com 14 maret 2016 